Helper, Vol 34 No 2 (2017) - 81

\title{
PENGARUH LATIHAN AUTOGENIC RELAXATION TERHADAP KONSENTRASI DAN KEBERHASILAN FREE THROW BOLABASKET
}

\author{
Yandika Fefrian Rosmi \\ Dosen FKIP Universitas PGRI Adi Buana Surabaya \\ Email: yfefrian@gmail.com
}

\begin{abstract}
Abstrak
Penelitian ini bertujuan untuk mengetahui: (1) Pengaruh dari latihan autogenic relaxation terhadap konsentrasi dapat meningkat dengan baik sesuai yang diharapkan pelatih, (2) Pengaruh dari latihan autogenic relaxation terhadap free throw dapat meningkat dengan baik sesuai yang diharapkan pelatih. Desain yang digunakan dalam penelitian ini adalah Rancangan penelitian two group pretest-posttests design. Dalam penelitian ini populasi penelitiannya adalah seluruh mahasiswa peserta UKM Bolabasket Universitas PGRI Adi Buana Surabaya aktif yang berjumlah 16 orang. Sampel dalam penelitian ini berjumlah 16 orang. Teknik pengambilan sampel dalam penelitian ini adalah sampling jenuh, yaitu teknik penentuan sampel bila semua anggota populasi digunakan sebagai sampel. Teknik análisis data menggunakan análisis statistik. Agar kesimpulan yang diperoleh dapat dipertanggung jawabkan kebenarannya maka sebelum analisis perlu dilakukan uji prasyarat perhitungan normalitas menggunakan kolmogorov smirnov, untuk kemudian dilakukan análisis data. Adapun teknik analisis data dalam penelitian ini ialah menggunakan uji-t (paired t-test). Hasil penelitian ini menunjukan terdapat pengaruh latihan autogenic relaxation terhadap konsentrasi dibuktikan dengan nilai thitung sebesar 12,322 dengan $p=0,000$, ternyata $p<0,05$. Terdapat pengaruh latihan autogenic relaxation terhadap tembakan free throw, dibuktikan dengan nilai thitung sebesar 6,065 dengan p=0,001, ternyata $p<0,05$.
\end{abstract}

\section{Kata Kunci: Autogenic Relaxation, Konsentrasi, Free throw}

\section{Latara Belakang Masalah}

Bola basket merupakan cabang olahraga permainan yang sangat populer. Di Indonesia, bola basket menunjukkan perkembangan ke arah yang positif, hal ini ditunjukan dengan banyaknya event-event bola basket yang digelar secara rutin. Bola basket sangat mudah dan menyenangkan untuk dimainkan, sehingga permainan ini sangat digemari oleh seluruh kalangan khususnya kalangan remaja baik pria maupun wanita. Kalangan remaja beranggapan bahwa melalui

"HELPER" Jurnal Bimbingan dan Konseling FKIP UNIPA 
bola basket segala kegiatan positif sekaligus prestasi bisa diperoleh. Penggemarnya yang berasal dari segala usia merasakan bahwa bola basket adalah olahraga yang menyenangkan, kompetitif, mendidik, menghibur, dan menyehatkan (Oliver, 2007: vi). Olahraga permainan bola basket salah satu dari permainan invasi yaitu permainan saling menyerang untuk memasukkan bola ke ring basket. Pemenang dalam olahraga permainan ini ditentukan dari perolehan point terbanyak.

Dalam olahraga bola basket ada beberapa gerak dasar yang perlu dikuasai, yaitu shoot (menembak), passing (mengumpan), dan dribble (menggiring bola). Dilihat dari karakteristik pemain bola basket di indonesia yang memunyai kecenderungan berpostur relatif pedek, shoot merupakan komponen yang paling penting dikuasai oleh setiap pemain. Gerak dasar shoot (menembak) merupakan segala usaha memasukkan bola ke dalam ring (basket) untuk memperoleh point atau nilai, hal ini sesuai dengan prinsip dasar permainan bola basket. Kemampuan ini yang membuat tujuan kemenangan bisa dicapai. Shoot terdiri dari bermacammacam teknik, antara lain jump shoot, lay up, set shoot, hook shoot dan semua macam gerakan dengan upaya memasukkan bola ke dalam ring. Melihat sangat pentingnya shoot pada permainan bola basket, maka peneliti mengangkat shoot untuk dibahas lebih lanjut, namun peneliti lebih memfokuskan pada tembakan hukuman atau free throw.

Berdasarkan pengalaman melatih dan observasi lapangan dengan mengamati beberapa pertandingan bolabasket, masih banyak kecenderungan atlet dalam melaksanakan tembakan free throw dengan tergesa-gesa dan kurang tenang dalam melakukan tembakan karena tertekan dengan waktu yang diberikan dari pelatih. Akibatnya konsentrasi atlet dalam melakukan tembakan free throw akan terganggu dan gagal dalam menciptakan point dari free throw karena mengalami penurunan kondisi mental. Penurunan kondisi mental tersebut disebabkan karena banyak 
faktor, yaitu: (1) pada saat berlatih tekanan yang dihadapi oleh atlet berasal dari pelatih dan rekan satu tim, (2) pada saat bertanding tekanan yang dihadapi berasal dari: (a) lawan, (b) penonton, (c) rekan satu tim, dan (d) batasan waktu pertandingan, (3) pada saat tes perkembangan kemampuan free throw tekanan yang dihadapi adalah rekan yang menjadi penonton dan batasan waktu tes. Faktor-faktor tersebut yang mengakibatkan konsentrasi atlet dapat terganggu dalam melakukan free throw, sehingga tingkat keberhasilan dalam melakukan free throw kurang maksimal atau bisa dikatakan kurang sukses dalam melakukan free throw.

\section{Perbedaan keberhasilan free} throw saat latihan, pertandingan, dan saat tes perkembangan atlet dalam melakukan free throw, mengindikasikan kondisi mental atlet yang belum stabil yang dapat mengganggu konsentrasi atlet dalam keberhasilan melakukan free throw. Upaya peningkatan mental atlet sehingga dapat meningkatkan konsentrasi atlet dan tingkat keberhasilan dalam melakukan free throw pada atlet sangat perlu dilakukan latihan mental yang berdampingan dengan latihan teknik dan fisik, sehingga dapat menunjang dalam meningkatkan konsentrasi dalam melakukan free throw dan keberhasilan dalam free throw. Pentingnya kondisi mental dalam melakukan free throw perlu dilakukan pembinaan mental dengan latihan relaksasi, bentuk latihan relaksasi yang dilakukan adalah latihan autogenic relaxation. Latihan tersebut merupakan proses latihan mental dengan melibatkan unsur konsentrasi, mengarahkan tindakan ke suatu tujuan sesuai rencana, pengendalian perasaan, dan psikofisik.

Berdasarkan permasalahan di atas akan dilakukan penelitian memberikan satu bentuk latihan relaksasi yaitu, latihan autogenic relaxation diharapkan dapat meningkatkan pemain baik teknik maupun mental dalam melakukan free throw shoot.

\section{Tinjauan kepustakaan}

a. Autogenic relaxation

Menurut Welz (2011) latihan otuogenik-rilaksasi dikembangkan oleh Schultz pada tahun 1932. Selama 
menjalani latihan otogenik-rilaksasi seseorang akan merasakan kondisi tubuh seperti hangat atau pun berat (http://www.welz.us/Otogenik.pdf).

Latihan otogenik-rilaksasi pada awalnya harus dipandu oleh instruksiinstruksi dari pelatih. Meski demikian, setelah beberapa kali latihan maka atlet dapat melakukan latihan otogenik rilaksasi sendiri. Pendapat lain menyatakan bahwa latihan otogenik rilaksasi merupakan latihan mandiri atau self-training yang menekankan pada self-suggestion atau pemberian sugesti pada diri sendiri (http://file.upi.edu//MODUL_6,_Taha pan_Model_dan_Teknik_Pelatihan_M ental.pdf). Menurut Ursula (2010: 7) menerangkan bahwa, Autogenic berasalan dari kata auto and genos dapat diartikan sebagai self-exercise, self-induced (latihan mandiri, stimulasi diri), latihan untuk mengaktifkan atau untuk mengkoneksikan pikiran dan tubuh. (http://hoymotivacion.com/wpcontent/uploads/2014/12/Autogenictraining,pdf). Ursula (2010: 9) juga menyatakan "autogenic therapy, as a stand-alone treatment can; (1) Help people switch from stress to relaxation at will, (2) Reduce or eliminate anxiety and panic attacks (3) Increase confidence and selfesteem, (4) Significantly improve sleep quality, (5) Reduce the incidence of mild to moderate depression (6) Offer a tool for self-empowerment and feeling to be more in control (7) Increase concentration and focus".

Latihan otogenik-rilaksasi dilakukan dengan memfokuskan pada area tubuh khusus yang dengan mengulang susunan kalimat sugestif. Pelaksanaan latihan otogenik-rilaksasi dilakukan melalui pengontrolan terhadap sistem syaraf otonom, seperti tekanan darah, temperatur kulit, dan detak jantung (Miftakhul Jannah, 2004: 40). Menurut Welz (2011) prosedur latihan otogenik-rilaksasi terdiri atas 6 langkah, yaitu: (1) merasakan berat tubuh, (2) merasakan kehangatan tubuh, (3) latihan denyut jantung, (4) latihan pernafasan, (5) latihan pada bagian perut, dan (6) latihan bagian kepala (http://www.welz.us/Otogenik.pdf).

b. Konsentrasi

Konsentrasi adalah kemampuan untuk memelihara fokus perhatiannya pada lingkungan yang relevan 
(Weinberg \& Gould, 2007: 367). Konsentrasi rnerupakan selective attention (perhatian yang memusat). Cox (2002: 32) menyatakan konsentrasi merupakan kemampuan atlet untuk memusatkan perhatian pada informasi yang relevan selama kompetisi. Komarudin (2013: 138) menambahkan konsentrasi adalah kemampuan untuk memusatkan perhatian pada tugas, dengan tidak terpengaruh stimulus yang bersifat eksternal maupun internal. Sukadiyanto (2006: 177) menyatakan bahwa perhatian dan konsentrasi merupakan salah satu bagian dari potensi psikologis atlet yang mendukung pencapaian prestasi optimal. Atlet yang kehilangan konsentrasi dalam pertandingan maupun latihan jelas akan mengalami kegagalan dalam mengeksekusi setiap respon dalam bentuk gerak pada cabang olahraga.

Pengertian-pengertian tentang konsentrasi di atas dapat disimpulkan bahwa konsentrasi merupakan proses pemusatan perhatian terhadap tugastugas tanpa terganggu stimulus baik dari internal maupun eksternal dengan rentang waktu yang relatif lama. Dari pengertian dan pendapat mengenai konsentrasi di atas juga diketahui empat ciri utama konsentrasi antara lain; (1) fokus pada suatu objek yang relevan (perhatian yang selektif), (2) memelihara fokus perhatian dalam jangka waktu lama, (3) memiliki kesadaran pada situasi, dan (4) meningkatkan fokus perhatian jika diperlukan.

Jenis konsentrasi ditentukan oleh dua hal yaitu keluasan (melebar dan menyempit) dan arah (ke dalam dan ke luar) (Weinberg \& Gould, 2003: 358). Konsentrasi yang meluas adalah kondisi seseorang dalam menerima beberapa kejadian (rangsang) secara simultan. Hal itu terjadi pada saat atlet harus menyadari dan peka terhadap perubahan lingkungan pertandingan yang biasanya mengganggu daya konsentrasi. Misalnya saat atlet bertanding di daerah yang terlalu panas padahal ketika latihan berada didaerah yang sejuk/dingin. Sedangkan konsentrasi menyempit adalah kondisi seseorang yang hanya menerima satu atau dua rangsang. Sebagai contoh pada 
saat pemain bola basket melakukan shooting, konsentrasinya berada pada ring dan bola. Selanjutnya, konsentrasi ke luar adalah fokus perhatian terhadap objek yang berada di luar diri seseorang, misalnya antara lain dapat berupa objek bola atau gerakan lawan. Sedangkan konsentrasi ke dalam adalah fokus perhatian yang mengarah pada pikiran dan perasaannya diri sendiri. Misalnya seorang shooter yang berkonsentrasi pada teknik ketika melakukan shooting.

Kombinasi dari kedua hal di atas akan membentuk empat jenis konsentrasi, yaitu konsentrasi yang (1) meluas ke luar, (2) menyempit ke luar, (3) meluas ke dalam, dan (4) menyempit ke dalam. Konsentrasi yang meluas ke luar merupakan upaya atlet untuk mengendalikan setiap perubahan yang terjadi di lingkungan pertandingan secara baik dan cepat. Misalnya, pemain bola basket yang akan mengumpan bola perlu mencermati posisi kawan dan posisi lawan, agar umpannya tepat dan tidak terebut oleh lawan.
Konsentrasi yang menyempit ke luar merupakan upaya atlet untuk fokus pada satu target atau menampilkan satu gerak yang fokusnya sudah jelas. Misalnya konsentrasi yang dilakukan pada saat melakukan shooting, memukul bola, saat awalan lompat jauh, atau lompat tinggi. Konsentrasi yang meluas ke dalam merupakan upaya atlet atau atlet untuk berpikir merencanakan strategi secara baik, melaksanakan taktik secara jitu, menganalisis lawan, dan mengantisipasi respon yang dilakukan oleh lawan. Konsentrasi yang menyempit ke dalam merupakan upaya atlet untuk fokus pada satu target, membayangkan penampilan yang dilakukan, mengontrol kondisi emosionalnya.

\section{c. Tembakan Free Throw}

Menembak dalam olahraga bola basket merupakan salah satu teknik yang sangat penting dimiliki setiap atlet bola basket, karena dengan menembak, perolehan angka yang didapat dari hasil tembakan akan menentukan kemenangan suatu tim. Menembak merupakan usaha yang dilakukan 
pemain untuk memasukkan bola ke dalam keranjang lawan dengan tujuan memperoleh angka atau skor sebanyakbanyaknya untuk memenangkan pertandingan. Setiap pemain berpotensi untuk menjadi seorang penembak yang baik, dengan latihan yang intensif hasil yang diperoleh akan maksimal. Menurut Oliver (2007: 32) penerapan dasar-dasar menembak yang benar secara konsisten adalah kunci untuk mendapatkan keberhasilan melakukan tembakan selama bermain dalam situasi-situasi pertandingan.

Dalam bola basket ada satu tembakan yang penting dikuasai setiap pemain bola basket yaitu free throw. Menurut Perbasi (2010:51) menyatakan "free throw adalah kesempatan yang diberikan kepada pemain untuk mencetak angka dari belakang garis tembakan hukuman di dalam setengah lingkaran”. NCAA (2014: 74) menambahkan bahwa "A free throw is the privilege given a player to score one point by an unhindered try for goal from within the free-throw semicircle and behind the freet hrow line. Artinya sebuah lemparan bebas adalah hak istimewa yang diberikan pemain untuk mencetak satu titik oleh mencoba tanpa hambatan untuk sasaran dari dalam setengah lingkaran lemparan bebas dan di belakang garis lemparan bebas. Lebih lanjut FIBA (2012: 45) menyatakan "A free throw is an opportunity given to a player to score one (1) point, uncontested, from a position behind the free-throw line and inside the semi-circle”. Maksudnya free throw merupakan kesempatan yang diberikan kepada pemain untuk mencetak satu (1) poin, tidak terbantahkan, dari posisi di belakang garis lemparan bebas dan di dalam setengah lingkaran.

Dari definisi-definisi tersebut di atas meskipun nampaknya sangat berbeda satu sama lain, karena mereka mengartikannya menurut pandangan mereka sendiri, tetapi dipandang secara kaseluruhan pendapat para ahli tersebut dapat saling melengkapi. Karena itu dari pendapat para ahli tersebut dapat ditarik kesimpulan bahwa free throw merupakan kesempatan yang diberikan kepada pemain untuk mencetak point melalui tembakan bebas yang diperoleh 
dari hukuman dan dilaksanakan di belakang garis pada paint area. Untuk lebih jelas mengenai free throw di bawah ini merupakan gambar lapangan bola basket yang juga menyajikan free throw lane.

Kemenangan sebuah tim terkadang ditentukan oleh keberhasilan dalam melakukan tembakan bebas atau free throw, dengan semakin baik mengeksekusi free throw semakin bertambah pula point atau nilai tim tersebut, dengan nilai yang tinggi tersebut akan dinyatakan sebagai pemenang. Kosasih (2009 : 51) menambahkan bahwa tembakan free throw sangat menentukan kemenangan atau kekalahan di dalam pertandingan, maka latihlah free throw di dalam setiap latihan. Wissel (2004: 64) menambahkan bahwa "most player use the one hand shot for a free thro,w taking the time to control each of basic mechanic: sighting, balance, hand position, elbow in alignment, shooting rhythm and follow trough". Artinya adalah sebagian besar pemain menggunakan tembakan satu tangan untuk melakukan free throw, meluangkan waktu untuk mengontrol setiap mekanik dasar seperti: keseimbangan, pengamatan posisi siku, ritme tembakan dan gerak lanjutan.

\section{Metode Penelitian}

Penelitian ini adalah penelitian eksperimen. Penelitian eksperimen ini menggunakan dua kelompok yang memperoleh perlakuan yang berbeda. Penelitian eksperimen merupakan penelitian yang dimaksudkan untuk mengetahui ada tidaknya akibat dari sesuatu yang dikenakan pada subjek selidik (Suharsimi, 2005: 207). An experiment is controlled observations of the effects of a manipulated independent variable on some dependent variable (Balnaves and Caputi, 2001: 68). Desain yang digunakan dalam penelitian ini adalah Rancangan penelitian two group pretest-posttests design. Menurut Suharsimi (2005: 212) "two group pretest-posttest design yaitu eksperimen yang dilaksanakan pada dua kelompok pembanding”. Desain ini diformulasikan sebagai berikut: 
Tabel 1.

Rancangan Penelitian Eksperimen

\begin{tabular}{|c|c|c|}
\hline $\begin{array}{c}\text { Konsentrasi dan free } \\
\text { throw shoot }\end{array}$ & Metode Latihan & $\begin{array}{c}\text { Konsentrasi dan free } \\
\text { throw shoot }\end{array}$ \\
\hline Pretest & \multirow{2}{*}{ Autogenic relaxation } & Posttest \\
\cline { 1 - 1 } Pretest & Posttest \\
\hline
\end{tabular}

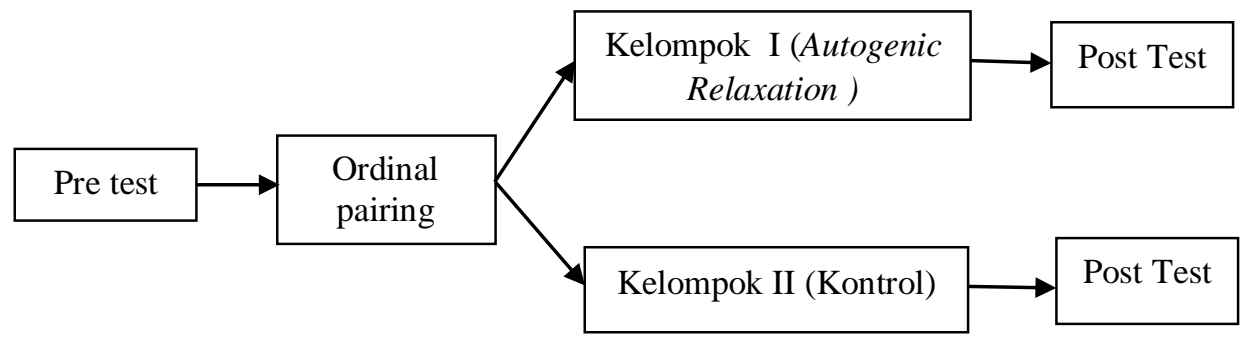

Gambar 2.

Desain Penelitian Two Group Pretest-Posttests Design

\section{Hasil dan pembahasan}

Sebelum dilakukan analisis data, akan dilakukan uji prasyarat analisis data yaitu uji normalitas. Uji prasyarat analisis disajikan berikut ini:
Pengujian normalitas sebaran data dipergunakan kolmogorov smirnov test yang dilakukan dengan bantuan software SPSS. Hasil analisis disajikan pad

a. Uji Normalitas Sebaran

a tabel berikut ini:

Tabel 7.

Hasil Uji Normalitas Sebaran

\begin{tabular}{|l|c|c|}
\hline \multirow{2}{*}{ Data } & \multicolumn{2}{c|}{} \\
\cline { 2 - 3 } & Sig. (p) & Keterangan \\
\hline Konsentrasi (Pre-test) Kelompok Perlakuan & 0,654 & Normal \\
\hline Free Throw (pre test) Kelompok Perlakuan & 0,937 & Normal \\
\hline Konsentrasi (Post-test) Kelompok Perlakuan & 0,999 & Normal \\
\hline Free Throw (post test) Kelompok Perlakuan & 0,699 & Normal \\
\hline Konsentrasi (Pre-test) Kelompok Kontrol & 0,394 & Normal \\
\hline Free Throw (pre test) Kelompok Kontrol & 0,825 & Normal \\
\hline Konsentrasi (Post-test) Kelompok Kontrol & 1.000 & Normal \\
\hline Free Throw (post test) Kelompok Kontrol & 0.888 & Normal \\
\hline
\end{tabular}


Tabel di atas memperlihatkan bahwa, uji normalitas pada data konsentrasi pre test dan post test baik pada kelompok perlakuan dan kelompok control didapatkan Kolmogorov Smirnov (KS) nilai p lebih besar dari 0,05. Hasil tersebut menunjukan bahwa data-data tersebut berdistribusi normal.

\section{b. Pengujian Hipotesis}

Hipotesis yang diuji pada penelitian ini adalah data yang yang diperoleh dari kelompok perlakuan dan kelompok kontrol: Hipotesis di atas diuji dengan menggunakan uji-t amatan ulangan (paired t-test);

\section{Data kelompok perlakuan (autogenic relaxation)}

\section{Pengujian hipotesis pertama}

Hipotesis pertama pada penelitian ini adalah: "Ada pengaruh positif dari latihan autogenic relaxation terhadap konsentrasi atlet putra UKM Bolabasket UNIPA Surabaya”. Hipotesis tersebut adalah hipotesis asli/alternatif (Ha), guna keperluan pengujian hipotesis, hipotesis tersebut diubah ke dalam hipotesis nihil/null hypothesis, yaitu: “Tidak ada pengaruh dari latihan autogenic relaxation terhadap konsentrasi atlet putra UKM Bolabasket UNIPA Surabaya”.

Hipotesis tersebut diuji menggunakan uji-t amatan ulangan (paired t-test), hasil analisis dengan bantuan software SPSS secara ringkas disajikan pada tabel berikut ini:

Table 8.

Hasil Analisis Uji-t Amatan Ulangan (Paired t-test) Data Konsentrasi pada Kelompok Autogenic relaxation.

\begin{tabular}{|l|c|c|c|c|c|}
\hline \multirow{2}{*}{ Konsentrasi } & \multirow{2}{*}{ Rerata } & \multirow{2}{*}{$\mathrm{SD}$} & \multicolumn{2}{|c|}{ Statistik } & \multirow{2}{*}{ Keterangan } \\
& & & $t_{\text {hitung }}$ & $p$-Value & \\
\hline - Post-test & 21,00 & 3,071 & \multirow{2}{*}{12,322} & 0,000 & \multirow{2}{*}{ Signifikan } \\
\hline - Pre-test & 13,12 & 3,271 & & & \\
\hline
\end{tabular}

Tabel tersebut di atas sebesar 12,322 dengan $p=0,000$, memperlihatkan bahwa berdasarkan ternyata $\mathrm{p}<0,05$ dengan demikian ada hasil analisis, didapatkan nilai $\mathrm{t}_{\text {hitung }}$ perbedaan bermakana antara hasil pre 
test dan hasil post test. Perbedaan tersebut disebabkan adanya perlakuan aktifitas fisik berupa latihan autogenic relaxation, sehingga dengan latihan tersebut berpengaruh terhadap konsentrasi. Dilihat dari rerata yang diperoleh, pada data post test lebih tinggi dibandingkan data pre test, dengan demikian pengaruhnya adalah positif.

Berdasarkan fakta tersebut, maka hipotesis nihil (Ho) yang menyatakan "Tidak ada pengaruh dari latihan autogenic relaxation terhadap konsentrasi atlet putra UKM Bolabasket UNIPA Surabaya”, ditolak, dan hipotesis alternatif (Ha) yang menyatakan "Ada pengaruh dari latihan autogenic relaxation terhadap konsentrasi atlet putra UKM Bolabasket UNIPA Surabaya", diterima. Artinya bahwa terdapat pengaruh latihan autogenic relaxation terhadap konsentrasi atlet putra tim UKM Bolabasket UNIPA Surabaya.

\section{Pengujian hipotesis kedua}

Hipotesis kedua pada penelitian ini adalah: "Ada pengaruh positif dari latihan autogenic relaxation terhadap keberhasilan tembakan free throw atlet putra UKM Bolabasket UNIPA Surabaya". Hipotesis tersebut adalah hipotesis asli/alternatif (Ha), guna keperluan pengujian hipotesis, hipotesis tersebut diubah ke dalam hipotesis nihil/null hypothesis, yaitu: "Tidak ada pengaruh dari latihan autogenic relaxation terhadap tembakan free throw atlet putra UKM Bolabasket UNIPA Surabaya”.

Hipotesis tersebut diuji menggunakan uji-t amatan ulangan (paired t-test), hasil analisis dengan bantuan software SPSS secara ringkas disajikan pada tabel berikut ini: 
Table 9.

Hasil Analisis Uji-t Amatan Ulangan (Paired t-test) Data Free Throw pada Kelompok Autogenic relaxation.

\begin{tabular}{|l|c|c|c|c|c|}
\hline \multirow{2}{*}{ Free Throw } & \multirow{2}{*}{ Rerata } & \multirow{2}{*}{$\mathrm{SD}$} & \multicolumn{2}{|c|}{ Statistik } & \multirow{2}{*}{ Keterangan } \\
\cline { 4 - 5 } & & & $t_{\text {hitung }}$ & $p$-Value & \\
\hline - Post-test & 8,00 & 1,852 & \multirow{2}{*}{6,065} & 0,001 & \multirow{2}{*}{ Signifikan } \\
\hline$\bullet$ Pre-test & 5,88 & 1,808 & & & \\
\hline
\end{tabular}

Tabel tersebut di atas

memperlihatkan bahwa

berdasarkan hasil analisis, didapatkan nilai thitung sebesar 6,065 dengan $\mathrm{p}=$ 0,001, ternyata $\mathrm{p}<0,05$ dengan demikian ada perbedaan bermakana antara hasil pre test dan hasil post test. Perbedaan tersebut disebabkan adanya perlakuan aktifitas fisik berupa latihan autogenic relaxation, sehingga dengan latihan tersebut berpengaruh terhadap free throw. Dilihat dari rerata yang diperoleh, pada data post test lebih tinggi dibandingkan data pre test, dengan demikian pengaruhnya adalah positif.

Berdasarkan fakta tersebut, maka hipotesis nihil (Ho) yang menyatakan "Tidak ada pengaruh dari latihan autogenic relaxation terhadap free throw atlet putra UKM Bolabasket UNIPA Surabaya", ditolak, dan hipotesis alternatif (Ha) yang menyatakan "Ada pengaruh dari latihan autogenic relaxation terhadap free throw atlet putra UKM Bolabasket UNIPA Surabaya", diterima. Artinya bahwa terdapat pengaruh latihan autogenic relaxation terhadap free throw atlet putra tim UKM Bolabasket UNIPA Surabaya.

\section{Data kelompok tanpa perlakuan (control) \\ Pengujian hipotesis pertama}

Hasil uji pada kelompok control menggunakan uji-t amatan ulangan (paired t-test), hasil analisis dengan bantuan software SPSS secara ringkas disajikan pada tabel berikut ini: 
Helper, Vol 34 No 2 (2017) - 93

Table 10.

Hasil Analisis Uji-t Amatan Ulangan (Paired t-test) Data konstrasi pada Kelompok kontrol.

\begin{tabular}{|l|c|c|c|c|c|}
\hline \multirow{2}{*}{ Free Throw } & \multirow{2}{*}{ Rerata } & \multirow{2}{*}{ SD } & \multicolumn{2}{|c|}{ Statistik } & \multirow{2}{*}{ Keterangan } \\
\cline { 3 - 5 } & & & $t_{\text {hitung }}$ & $p$-Value & \\
\hline - Post-test & 14,50 & 2,878 & \multirow{2}{*}{0,306} & 0,768 & $\begin{array}{c}\text { Tidak } \\
\text { Signifikan }\end{array}$ \\
\hline
\end{tabular}

Tabel tersebut di atas perlakuan apapun baik pada pre test dan memperlihatkan bahwa berdasarkan hasil analisis, didapatkan nilai thitung post test.

sebesar 0,306 dengan $p=0,768$, Pengujian hipotesis kedua ternyata $\mathrm{p}>0,05$ dengan demikian tidak Hasil uji pada kelompok control ada perbedaan bermakana antara hasil pre test dan hasil post test. Hal tersebut disebabkan karena tidak terdapat i:

Table 10.

Hasil Analisis Uji-t Amatan Ulangan (Paired t-test) Data free throw pada Kelompok kontrol.

\begin{tabular}{|l|c|c|c|c|c|}
\hline \multirow{2}{*}{ Free Throw } & \multirow{2}{*}{ Rerata } & \multirow{2}{*}{$\mathrm{SD}$} & \multicolumn{2}{|c|}{ Statistik } & \multirow{2}{*}{ Keterangan } \\
\cline { 5 - 5 } & & & $t_{\text {hitung }}$ & $p$-Value & \\
\hline - Post-test & 6,00 & 1,852 & \multirow{2}{*}{0,893} & 0,402 & $\begin{array}{c}\text { Tidak } \\
\text { Signifikan }\end{array}$ \\
\hline
\end{tabular}

Tabel tersebut di atas ada perbedaan bermakana antara hasil memperlihatkan bahwa berdasarkan hasil analisis, didapatkan nilai thitung sebesar 0,893 dengan $\mathrm{p}=0,402$, ternyata $\mathrm{p}>0,05$ dengan demikian tidak pre test dan hasil post test. Hal tersebut disebabkan karena tidak terdapat perlakuan apapun baik pada kelompok pre test dan post test 


\section{c. Pembahasan Hasil Penelitian}

Free throw dalam bolabasket menjadi hal yang penting karena dengan memaksimalkan free throw tujuan bermain bola basket yaitu kemenangan bisa tercapai. Dengan memeksimalkan kemampuan free throw sering kali sebuah tim mendapat keuntungan-keuntungan seperti mempertahankan kemenangan, mengejar perolehan point. Itulah sebabnya mengapa free throw dianggap penting dalam olahraga bolabasket. Apalagi jika selisih angka kedua tim yang bertanding hanya selisih satu angka. Bahkan tidak jarang tembakan free throw menjelang akhir dari pertandingan menjadi penentu kemenangan. Untuk dapat melakukan tembakan free throw atlet harus mempertimbangkan beberapa hal, seperti kemampuan teknik yang dimiliki, konsentrasi, dan kondisi mental. Apalagi dalam suatu pertandingan seringkali teknik tembakan free throw menjadi sangat tidak efektif akibat kondisi mental yang menurun, sebab dengan menurunnya kondisi mental akan dapat mempengaruhi atlet dalam berkonsentrasi untuk melakukan tembakan free throw.

Hal tersebut sesuai dengan apa yang dinyatakan Oliver (2007: 30) bahwa setiap melakukan free throw, penembak yang berhasil umumnya melakukan persiapan pratembakan yaitu konsentrasi. Konsentrasi membantu fisik dan mental dalam melakukan free throw yang mulus dan lancar. Sedangkan Priyanto (2012: 103) menyatakan sukses dalam melakukan tembakan bebas atau free throw memerlukan keahlian, kebiasaan, konsentrasi dan keyakinan. Sedangkan menurut Wissel (2004: 64) “Successful free throw shooting requires sound mechanics, a routine, relaxation, rhythm, consentration, and confidence. routine, relaxation, and rhythm contribute to concentration and confidence" artinya keberhasilan dalam menembak tembakan bebas membutuhkan rutinitas, relaksasi, ritme, konsentasi dan percaya diri.

Pada atlet putra tim UKM bolabasket UNIPASurabaya semua atlet memiliki teknik untuk melakukan 
tembakan free throw, hanya saja teknik tembakan free throw tersebut seringkali tidak menghasilkan angka baik pada saat latihan, tes kemampuan setiap bulan ataupun pertandingan. Hal tersebut dikarenakan penurunan kondisi mental yang mengganggu konsentrasi atlet dalam melakukan tembakan free throw. Penurunan kondisi mental pada atlet putra peserta UKM bolabasket UNIPA Surabaya tersebut disebabkan karena banyak faktor, yaitu: (1) pada saat berlatih tekanan yang dihadapi oleh atlet berasal dari pelatih dan rekan satu tim, (2) pada saat bertanding tekanan yang dihadapi berasal dari: (a) lawan, (b) penonton, (c) rekan satu tim, dan (d) batasan waktu pertandingan, (3) pada saat tes perkembangan kemampuan tembakan free throw tekanan yang dihadapi adalah rekan yang menjadi penonton dan batasan waktu tes. Faktor-faktor tersebut yang mengakibatkan konsentrasi atlet dapat terganggu dalam melakukan tembakan free throw, sehingga tingkat keberhasilan dalam melakukan tembakan free throw kurang maksimal atau bisa dikatakan kurang sukses dalam melakukan tembakan free throw. Perbedaan keberhasilan tembakan free throw saat latihan, pertandingan, dan saat tes perkembangan atlet dalam melakukan tembakan free throw, mengindikasikan kondisi mental atlet yang belum stabil yang dapat mengganggu konsentrasi atlet dalam keberhasilan melakukan tembakan free throw.

Penelitian ini berusaha untuk mengetahui latihan apa yang tepat untuk meningkatkan tingkat konsentrasi atlet dan meningkatkan keberhasilan atlet melakukan tembakan free throw. Dalam hal ini peneliti memebrikan satu formula yang dinilai mampu menjawab permasalahan di atas yaitu dengan melakukan latihan autogenic relaxation. Ternyata setelah mendapat latihan autogenic relaxation konsentrasi atlet dan keberhasilan dalam tembakan free throw meningkat. Itu artinya bahwa latihan autogenic relaxation mampu meningkatkan konsentrasi atlet dan keberhasilan tembakan free throw.

Para ahli mengatakan Latihan autogenic relaxation merupakan salah 
satu metode latihan untuk merubah kondisi stress menjadi relax, meredam kecemasan dan serangan panic, menambah percaya diri, control perasaan, menambah konsentrasi dan fokus, selain itu juga membantu dalam tidur yang berkualitas. Latihan autogenic relaxation merupakan sebuah metode latihan dengan memberikan sugesti, latihan dengan metode ini bisa dilakukan sendiri. Meskipun pada permulaan latihan, diperlukan instruksi-instruksi dari pelatih. Tapi setelah beberapa kali latihan, atlet harus bisa mensugesti dirinya sendiri dalam latihan relaksasi ini. Kenapa itu latihan ini terkenal dengan sebutan latihan mandiri atau self-training Hal ini juga menjadi alasan pemilihan metode latihan relaksasi ini untuk diteliti. Latihan otogenik-rilaksasi dilakukan dengan memfokuskan pada area tubuh khusus yang dengan mengulang susunan kalimat sugestif. Pelaksanaan latihan otogenik-rilaksasi dilakukan melalui pengontrolan terhadap sistem syaraf otonom, seperti tekanan darah, temperatur kulit, dan detak jantung
(Miftakhul Jannah, 2004: 40). Menurut Welz (2011) prosedur latihan otogenikrilaksasi terdiri atas 6 langkah, yaitu: (1) merasakan berat tubuh, (2) merasakan kehangatan tubuh, (3) latihan denyut jantung, (4) latihan pernafasan, (5) latihan pada bagian perut, dan (6) latihan bagian kepala.

Cara tersebut yang digunakan untuk meningkatkan kondisi fisik dan psikis atlet menjadi lebih baik, sehingga ketika melakukan tembakan free throw pikiran tenang dengan kondisi tubuh rileks, berkonsentrasi penuh dan sukses dalam melakukan tembakan free throw. Dari metode latihan relaksasi ini ternyata memberikan pengaruh yang signifikan terhadap konsentrasi dan keberhasilan tembakan free throw atlet putra UKM bolabasket UNIPA Surabaya. Karena menurut para ahli dengan melakukan latihan tersebut dapat membangkitkan Endorphins yaitu neurohormon yang berhubungan dengan sensasi menyenangkan, sehingga dapat memberikan ketenangan untuk meningkatkan konsentrasi dan 
memperbaiki teknik keterampilan yang dilakukan dalam penelitian ini.

Setelah dilakukan penelitian diperoleh hasil latihan autogenic relaxation terhadap konsentrasi atlet putra peserta UKM bolabasket UNIPA Surabaya terbukti berpengaruh. Hal ini dibuktikan analisis dengan uji t amatan ulangan dan didapatkan $t_{\text {hitung }}$ sebesar 12,322 dan $\mathrm{p}<0,05$. Dilihat dari rerata yang diperoleh, pada data post-test $(21,00)$ lebih tinggi dibandingkan data pre-test $(13,12)$. Latihan autogenic relaxation terhadap autogenic relaxation atlet putra tim UKM UNIPA Surabaya terbukti berpengaruh. Hal tersebut dibuktikan analisis dengan uji$\mathrm{t}$ amatan ulangan dan didapatkan $\mathrm{t}_{\text {hitung }}$ sebesar 6,065 dan $\mathrm{p}<0,05$. Dilihat dari rerata yang diperoleh, pada data posttest $(8,00)$ lebih tinggi dibandingkan data pre-test $(5,88)$.

\section{DAFTAR PUSTAKA}

Anonim. (2011). Tahapan dan teknik pelatihan mental atlet. (http://file.upi.edu/MODUL_6, _Tahapan_Model_dan_Teknik _Pelatihan_Mental.pdf).
Balnaves, M \& Caputi, P. (2001). Introduction to quantitative research methods. London: SAGE Publications Ltd

Cox, R. H. (2002). Sport psychology, $\left(5^{\text {th }}\right.$ ed). New York: The McGraw-Hill Company, Inc.

Danny Kosasih. 2008. Basketball

Fundamental. Semarang : Karang Turi Media.

FIBA. (2012). Official basketball rules. Rio De Janeiro: FIBA Central Board.

Komarudin. (2013). Psikologi Olahraga. Bandung: PT Remaja Rosdakarya.

Miftakhul Jannah. (2004). Pelatihan Meditasi-Otogenik untuk Meningkatkan Konsentrasi pada Atlet Lari Jarak Pendek. Tesis. Yogyakarta: Fakultas Psikologi UGM.

Oliver, J. (2007). Dasar-dasar bola basket. Bandung: Pakar Raya.

Perbasi, (2001). Peraturan permainan bolabasket. Jakarta: PB Perbasi.

Priyanto. (2012). Pengaruh metode latihan wall shooting dan mata tertutup terhadap hasil shooting free throw. Tesis magister, tidak diterbitkan, Universitas Negeri Semarang. 
Suharsimi Arikunto. (1998). Prosedur

Penelitian: suatu pendekatan praktis. Jakarta: Rineka Cipta. . (2002). Prosedur Penelitian. Jakrta: PT Rineka Cipta.

(2005).

Manajemen Penelitian. Edisi revisi. Jakarta: PT. Asdi Mahasatya.

Sukadiyanto. (2005). Teori dan metodologi melatih fisik. Yogyakarta: Penerbit UNY.
Ursula. V. W (2010). Autogenic Training. (http://hoymotivacion.com/wpcontent/uploads/2014/12/Autog enic-training-presentation.pdf).

Weinberg \& Gould. (2007). Foundations of sport and exercise phychology. Canada: Human Kinetics.

Welz, Karl Hans. (2011). Autogeic training.

(http://www.welz.us/Autogenic .pdf).

Wissel, Hal. (2004). Basketball step to sukses. $\quad 2^{\text {nd }} e d$. Champaign: Human Kinetics, Inc. 